\title{
In Vitro Rapid Multiplication of a Highly Valuable Ornamental Aquatic Plant Anubias Heterophylla
}

\author{
Suphat Rittirat ${ }^{1, *}$, Kanchit Thammasiri ${ }^{2}$ and Sutha Klaocheed ${ }^{3}$ \\ ${ }^{I}$ Faculty of Science and Technology, Nakhon Si Thammarat Rajabhat University, \\ Nakhon Si Thammarat 80280, Thailand \\ ${ }^{2}$ Department of Plant Science, Faculty of Science, Mahidol University, Bangkok 10400, Thailand \\ ${ }^{3}$ Department of Technology and Industries, Faculty of Science and Technology, \\ Prince of Songkla University, Pattani campus, Pattani 94000, Thailand
}

('Corresponding author's e-mail: suphat.nstru@gmail.com)

Received: 6 May 2020, Revised: 12 May 2021, Accepted: 18 May 2021

\begin{abstract}
The present study focuses on the development of a micropropagation protocol for true to type plants of Anubias heterophylla, a valuable ornamental aquatic plant. Natural propagation of aquatic species is limited due to the production of a small number of plants with a long cultivation period, disease and requirement of a large space for propagation. Surface-disinfected shoot tip explants were cultured on MS medium containing $0.1 \%(\mathrm{w} / \mathrm{v})$ activated charcoal (AC) and supplemented with 6-benzylaminopurine (BAP) at different concentrations $(0,1.0,3.0$ and $5.0 \mathrm{mg} / \mathrm{L})$ either singly or in combination with $\alpha$-Naphthalene acetic acid (NAA) and 2,4-Dichlorophenoxy acetic acid (2,4-D) $(0.5$ and $1.0 \mathrm{mg} / \mathrm{L})$. Among different auxins and cytokinin used, the number of shoots initiated per explant varied significantly among the different auxin and cytokinin combinations. The highest number of shoots per explants $(3.60 \pm$ 0.24 ) was formed in the culture medium containing $1.0 \mathrm{mg} / \mathrm{L} \mathrm{NAA}$ in combination with $1.0 \mathrm{mg} / \mathrm{L} \mathrm{BAP}$, followed by in the culture medium with $3.0 \mathrm{mg} / \mathrm{L}$ BAP $(2.40 \pm 0.24)$. In the culture medium with 1.0 $\mathrm{mg} / \mathrm{L}$ NAA and $1.0 \mathrm{mg} / \mathrm{L}$ BAP, $100 \%$ of the cultured explants regenerated new shoots within 60 days. The maximum number of roots (19.80 \pm 0.20 roots) per explant was observed after 60 days of culture on MS medium contained $0.1 \%(\mathrm{w} / \mathrm{v})$ AC and supplemented with $1.0 \mathrm{mg} / \mathrm{L} \mathrm{NAA}$ and $1.0 \mathrm{mg} / \mathrm{L}$ BAP. With a $100 \%$ survival rate, the regenerated plantlets were effectively acclimatized to submerged underwater environments. Plantlets exhibited phenotypic traits that were comparable to those of their donor plant. This protocol is suited for commercial Anubias heterophylla propagation in the aquarium industry.
\end{abstract}

Keywords: Aquatic plant, Auxins, Cytokinins, Micropropagation, Plant growth regulators

\section{Introduction}

Anubias heterophylla is a popular aquaria plant. A. heterophylla is a typical Anubias species that may be found in planted aquarium tanks at medium to big proportions. Anubias can be found growing on rocks at stream margins, partially emerged and submerged in its natural environment, making it an excellent choice for aquarium tanks and terrarium-like, emerged settings. A. heterophylla, like most Anubias, is quite forgiving in nature, and is easily loved by hobbyists of all skill levels due to its hardy nature and ability to adapt well to a wide range of aquarium tank parameters. A. heterophylla is a bold green in hue and its leaves are fairly large with a slight wave. It has the potential to grow much larger when kept in its emerged state and will stay on the smaller side when kept in an aquarium fully submerged [1]. Like other Anubias, Bucephalandra and Java Ferns, A. heterophylla does best when attached securely to aquarium hardscapes such as aquascaping stones or aquarium driftwood. Alternatively, it can also be placed between cracks in an aquascape layout, and it will attach itself over time. Care should be taken to ensure its roots are not glued when attaching as this can promote the rotting of the plant. Anubias benefits from consistent fertilization, but light requirements are minimal as its leaves are susceptible to algae growth when placed under high lighting. $\mathrm{CO}_{2}$ is optional but can promote faster growth and robust leaves when used [1].

Anubias can be propagated vegetatively using stolon division; however, stolon division is an inefficient propagation method for commercial purposes since the planting material has a very low 
multiplication rate. Micropropagation is currently applied to aquatic plants as a tool for the large scale multiplication of elite plants [2,3]. Micropropagation is a common method for the rapid and large-scale production of many ornamental aquatic plant species, including some Anubias species, such as Anubias barteri var. nana [4], Cryptocoryne wendtii [5], Aponogeton madagascariensis [2] and Nymphoides coreana [3]. However, to the best of our knowledge, in vitro propagation of $A$. heterophylla has not been reported before. The present research aimed to develop an effective protocol for the micropropagation of this species.

In vitro propagation is an important approach for mass multiplication and genetic resource conservation of many plant species, especially those under the threat of extinction for destruction or other natural reasons [6-9]. Propagation via division has been the most commonly used method for bulbous plants; however, the use of division risks the permanent loss of mother bulbs, and divisions are often limited by their intrinsic low regeneration rate and long juvenility [10].

In this paper, we present a plantlet regeneration protocol based on A. heterophylla shoot tips culture. For clonal progenies that are phenotypically homogeneous and grow without chromosomal alterations or meiotic abnormalities, in vitro shoot tip culture is commonly employed. The protocol comprises only 1 part: the induction of in vitro-derived plantlets from a shoot tip explant. The current investigation deals with the initiation of aseptic cultures of $A$. heterophylla from shoot tip explants, optimization of culture medium for shoot proliferation and rooting micro shoots and hardening of rooted micro shoots. Therefore, the objective of this investigation was to study the effects of auxins with BAP on a shoot and root development of $A$. heterophylla.

\section{Materials and methods}

\section{Plant materials, explant preparation and sterilization}

Young plantlets of $A$. heterophylla were obtained from the Aquatic Plant Center Co., Ltd., Thailand. Shoots were excised from 90-day-old mother plants and were washed thoroughly under running tap water. The shoots were surface-sterilized using $15 \%$ Clorox ${ }^{\circledR}(5.25 \%$ sodium hypochlorite, $\mathrm{NaOCl})$ and 2 - 3 drops of Tween-20 per $100 \mathrm{~mL}$ solution for $15 \mathrm{~min}$, followed by rinsing 3 times with sterile distilled water. They were again surface sterilized for another $10 \%$ Clorox ${ }^{\circledR}(5.25 \% \mathrm{NaOCl})$ and $2-3$ drops of Tween-20 per $100 \mathrm{~mL}$ solution for $10 \mathrm{~min}$ and $5 \%$ Clorox ${ }^{\circledR}(5.25 \% \mathrm{NaOCl})$ and 2 - 3 drops of Tween20 per $100 \mathrm{~mL}$ solution for $5 \mathrm{~min}$. The treated plantlets were washed 3 times with sterile distilled water to remove traces of disinfectant. The surface-sterilized shoot tip segments of $0.5 \mathrm{~cm}$ in length were excised aseptically and inoculated into bottles containing Murashige and Skoog (MS) medium [11] without plant growth regulators for 7 days. The culture bottles were sealed with Parafilm and incubated under a $16 \mathrm{~h}$ photoperiod with light supplied by cool-white fluorescent lamps at an intensity of $10 \mu \mathrm{mol} \mathrm{m} \mathrm{m}^{-2} \mathrm{~s}^{-1}$ photosynthetic photon flux density (PPFD).

\section{Culture media and conditions}

Murashige and Skoog (MS) media [11] supplemented with $0.1 \%$ (w/v) activated charcoal (AC) and $3 \%(\mathrm{w} / \mathrm{v})$ sucrose as a carbon source and gelled with $0.76 \%(\mathrm{w} / \mathrm{v})$ agar (commercial grade) were used as basal media throughout the experiment. Various concentrations and combinations of plant growth regulators (PGRs) (BAP; 0, 1.0, 3.0 and $5.0 \mathrm{mg} / \mathrm{L}, \mathrm{NAA} ; 0.5$ and $1.0 \mathrm{mg} / \mathrm{L}, 2,4-\mathrm{D} ; 0.5$ and $1.0 \mathrm{mg} / \mathrm{L}$ ) were added to different cultures. The $\mathrm{pH}$ of the media was adjusted to 5.7 with $1 \mathrm{~N} \mathrm{KOH}$ or $1 \mathrm{~N} \mathrm{HCl}$ prior to autoclaving for $15 \mathrm{~min}$ at $121{ }^{\circ} \mathrm{C}$. All cultures were aseptically maintained at $25 \pm 2{ }^{\circ} \mathrm{C}$ air temperatures under a $16 \mathrm{~h}$ photoperiod with light supplied by cool-white fluorescent lamps at an intensity of $10 \mu \mathrm{mol} \mathrm{m} \mathrm{m}^{-2}$ photosynthetic photon flux density (PPFD). Plant materials were stored in glass-capped culture jars (115 mL capacity) each containing $25 \mathrm{~mL}$ of medium.

\section{Effects of auxins with BAP on a shoot and root development of Anubias heterophylla after 60 days of culture}

Shoot tip explants $(0.5 \mathrm{~cm}$ in length) of 7 days old in vitro were placed on MS medium containing $0.1 \%(\mathrm{w} / \mathrm{v})$ activated charcoal (AC) and supplemented with 6-benzylaminopurine (BAP) at different concentrations $(0,1.0,3.0$ and $5.0 \mathrm{mg} / \mathrm{L})$ either singly or in combination with $\alpha$-Naphthalene acetic acid (NAA) and 2,4-Dichlorophenoxy acetic acid (2,4-D) $(0.5$ and $1.0 \mathrm{mg} / \mathrm{L})$. The maximum percentage of shoot proliferation, number of shoots per explant, shoot length $(\mathrm{mm})$, number of leaves per explant, leaf length $(\mathrm{mm})$, leaf width $(\mathrm{mm})$, the percentage of root formation, number of roots per shoot, and root length $(\mathrm{mm})$ were recorded and compared statistically after 60 days of culture (starting from the initial day of inoculation). A set of cultures without plant growth regulators (PGRs) served as the control. 


\section{Hardening and establishment of tissue culture plantlets}

Plantlets of $A$. heterophylla with well-developed shoots and roots were removed from the culture medium, washed gently with a soft brush in tap water to remove the adhering agar-agar with plant tissue. The plantlets were then transplanted into small clay pots containing tap water under greenhouse conditions. The plantlets were grown in the greenhouse with $80-90 \%$ relative humidity and about $12 \mathrm{~h}$ photoperiod, $300-400 \mu \mathrm{mol} \mathrm{m} \mathrm{m}^{-2} \mathrm{~s}^{-1}$ photosynthetic photon flux density (PPFD) (shaded sunlight) and 28 \pm 2 to $24 \pm 2{ }^{\circ} \mathrm{C}$ day/night temperature. After 30 days in the greenhouse, the survival rate of acclimatized plantlets was recorded.

\section{Experimental design and statistical analysis}

The data were collected after 60 days from a shoot and root development. All the experiments were conducted in a completely randomized design (CRD) with 5 replicates per treatment and the experiments were repeated 3 times. The results are expressed as mean \pm SE of 1 experiment. The data were analyzed by ANOVA using SPSS version 20 and the mean values were separated using Duncan's multiple range test (DMRT) at a $5 \%$ probability level.

\section{Results and discussion}

Effects of auxins with BAP on a shoot and root development of Anubias heterophylla after 60 days of culture

An effective micropropagation method was done for the in vitro plant regeneration of A. heterophylla. For establishing a plant regeneration protocol, the current study investigated the effects of auxins with BAP on shoot and root development of A. heterophylla after 60 days of culture.

Regeneration potential of shoot tip explants of $A$. heterophylla was explored on MS medium containing $0.1 \%(\mathrm{w} / \mathrm{v})$ activated charcoal (AC) and supplemented with 6-benzylaminopurine (BAP) at different concentrations $(0,1.0,3.0$ and $5.0 \mathrm{mg} / \mathrm{L})$ either singly or in combination with $\alpha$-Naphthalene acetic acid (NAA) and 2,4-Dichlorophenoxy acetic acid (2,4-D) $(0.5$ and $1.0 \mathrm{mg} / \mathrm{L})$ and the results were summarized in Tables 1 and $\mathbf{2}$. The synergistic influence of auxins with cytokinin was evident when the combination of optimal concentrations of cytokinin with different concentrations of NAA and 2,4-D (0.5 and $1.0 \mathrm{mg} / \mathrm{L}$ ) were tested (Table 1). The results showed that there was a significant difference in the effect of type and concentration of PGRs on vegetative traits of A. heterophylla in the proliferation stage $(p \leq 0.05)$. The lowest shoot proliferation percentage $(30.00 \pm 0.12)$ and the average number of shoots multiplied per single shoot tip explant $(1.00 \pm 0.00$ shoot $)$ developed in the absence of plant growth regulators (Table 1 and Figure 1A). The number of shoots initiated per explant varied significantly among the different auxin and cytokinin combinations (Table 1 and Figure 1). The highest number of shoots per explants $(3.60 \pm 0.24)$ was formed in the culture medium containing $1.0 \mathrm{mg} / \mathrm{L}$ NAA in combination with $1.0 \mathrm{mg} / \mathrm{L}$ BAP (Table 1 and Figure 1C), followed by in the culture medium with 3.0 $\mathrm{mg} / \mathrm{L}$ BAP $(2.40 \pm 0.24)$ (Table 1 and Figure 1B). In the culture medium with $1.0 \mathrm{mg} / \mathrm{L}$ NAA and 1.0 $\mathrm{mg} / \mathrm{L}$ BAP, $100 \%$ of the cultured explants regenerated new shoots within 60 days. NAA also enhanced the number of shoots per explant (3.60 $\pm 0.24-2.00 \pm 0.00$ shoots per explant) but the presence of 2,4-D in the medium drastically reduced the number of shoots per explant. In the case of 2,4-D, the highest number of shoots per explant $(1.40 \pm 0.24$ shoots $)$ was achieved from shoot tip explants on MS medium containing $1.0 \mathrm{mg} / \mathrm{L} \mathrm{2,4-D}$ and $3.0 \mathrm{mg} / \mathrm{L}$ BAP (Table 1 and Figure 1E). No callus formation was achieved when shoot tip segments were used as explants. The lowest shoot multiplication was observed on MS medium containing $0.1 \%$ (w/v) AC (control, $1.00 \pm 0.00$ shoots) or MS medium contained $0.1 \%$ $(\mathrm{w} / \mathrm{v}) \mathrm{AC}$ and supplemented with $0.5 \mathrm{mg} / \mathrm{L} 2,4-\mathrm{D}$ and $1.0,3.0,5.0 \mathrm{mg} / \mathrm{L} \mathrm{BAP}(1.00 \pm 0.00$ shoots $)$ or 1.0 $\mathrm{mg} / \mathrm{L} 2,4-\mathrm{D}$ and $0.0,1.0,5.0 \mathrm{mg} / \mathrm{L} \mathrm{BAP}(1.00 \pm 0.00$ shoots) (Table 1). 

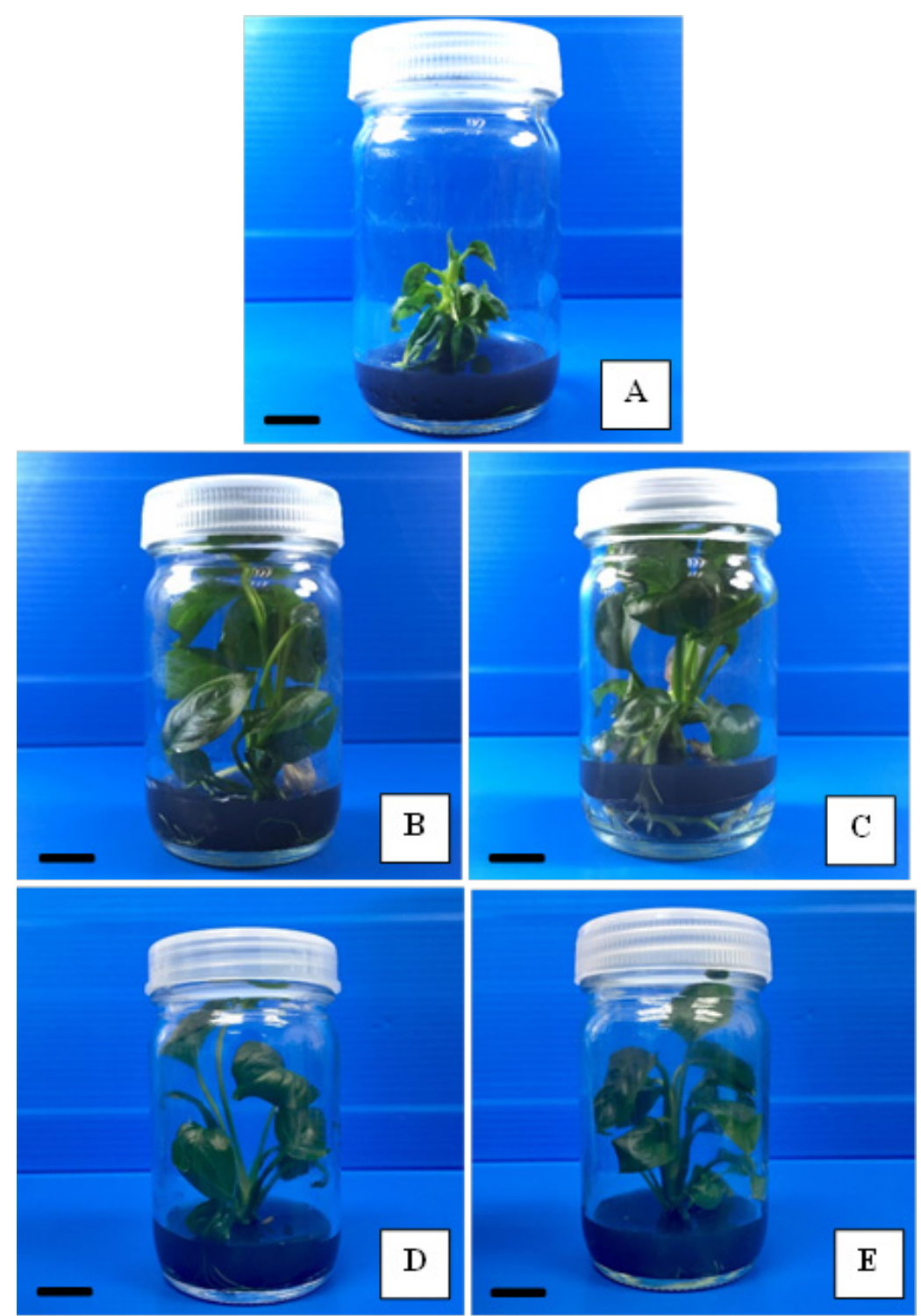

Figure 1 In vitro propagation of Anubias heterophylla; multiple shoots formation from shoot tip explants after 60 days cultured on agar-gelled MS medium supplemented with $0.1 \%(\mathrm{w} / \mathrm{v})$ activated charcoal (AC) and plant growth regulators. (A) Control, (B) $3.0 \mathrm{mg} / \mathrm{L} \mathrm{BAP,} \mathrm{(C)} 1.0 \mathrm{mg} / \mathrm{L} \mathrm{NAA}+1.0 \mathrm{mg} / \mathrm{L}$ BAP, (D) $0.5 \mathrm{mg} / \mathrm{L} 2,4-\mathrm{D}$ and (E) $1.0 \mathrm{mg} / \mathrm{L} 2,4-\mathrm{D}+3.0 \mathrm{mg} / \mathrm{L} \mathrm{BAP}($ Scale bar $=1 \mathrm{~cm})$.

In the case of BAP alone, the highest number of shoots per explant $(2.40 \pm 0.24$ shoots $)$, shoot length $(72.40 \pm 0.24)$ number of leaves $(10.80 \pm 0.73$ leaves $)$, leaf length $(39.35 \pm 0.12 \mathrm{~mm})$, and leaf width $(25.44 \pm 0.82 \mathrm{~mm})$ was achieved from shoot tip explants on MS medium contained $0.1 \%(\mathrm{w} / \mathrm{v}) \mathrm{AC}$ and supplemented with $3.0 \mathrm{mg} / \mathrm{L}$ BAP (Table 1 and Figure 1B). The elongation of shoots was significantly better on medium containing $1.0 \mathrm{mg} / \mathrm{L} \mathrm{NAA}$ and $1.0 \mathrm{mg} / \mathrm{L} \mathrm{BAP}(76.40 \pm 0.97 \mathrm{~mm})$ (Table 1 and Figure 1C) than in the presence of $1.0 \mathrm{mg} / \mathrm{L} \mathrm{2,4-D}$ supplemented with $1.0 \mathrm{mg} / \mathrm{L}$ BAP $(54.60 \pm 0.52$ $\mathrm{mm}$ ) (Table 1). The lowest elongation of shoots was observed on MS medium containing $0.1 \%(\mathrm{w} / \mathrm{v})$ AC $(15.00 \pm 0.00)$ (Table 1 and Figure 1A). A significant difference in the number of leaves was detected among the treatments containing NAA, 2,4-D and BAP. Regenerated shoots had a higher number of leaves on MS medium supplemented with $0.1 \%(\mathrm{w} / \mathrm{v})$ AC and contained auxins with cytokinins. The maximum number of leaves per shoot (18.20 \pm 0.73 leaves per explant), leaf length $(42.44 \pm 0.81 \mathrm{~mm})$ and leaf width $(26.20 \pm 0.90 \mathrm{~mm})$ were observed in MS medium containing $0.1 \%$ (w/v) AC and supplemented with $1.0 \mathrm{mg} / \mathrm{L}$ NAA and $1.0 \mathrm{mg} / \mathrm{L}$ BAP. The leaves of the regenerated shoots were healthy with dark green color and did not show any sign of vitrification. 
Table 1 Effects of auxins with BAP on shoot development of Anubias heterophylla after 60 days of culture. All culture mediums were added with $0.1 \%(\mathrm{w} / \mathrm{v}) \mathrm{AC}$.

\begin{tabular}{|c|c|c|c|c|c|c|c|c|}
\hline \multirow[b]{2}{*}{ NAA } & \multicolumn{2}{|c|}{$\begin{array}{l}\text { Growth } \\
\text { regulators } \\
\text { (mg/L) }\end{array}$} & \multirow{2}{*}{$\begin{array}{c}\text { Shoot } \\
\text { proliferation } \\
(\%) \\
(\text { mean } \pm \mathrm{SE})^{\mathrm{a}}\end{array}$} & \multirow{2}{*}{$\begin{array}{c}\text { Number of } \\
\text { shoots per } \\
\text { explant } \\
(\text { mean } \pm \mathrm{SE})^{\mathrm{a}}\end{array}$} & \multirow{2}{*}{$\begin{array}{l}\text { Shoot length } \\
\quad(\mathrm{mm})\end{array}$} & \multirow{2}{*}{$\begin{array}{c}\text { Number of leaves } \\
\text { per explant } \\
(\text { mean } \pm \mathrm{SE})^{\mathrm{a}}\end{array}$} & \multirow{2}{*}{$\begin{array}{l}\text { Leaf length } \\
\quad(\mathrm{mm}) \\
(\mathrm{mean} \pm \mathrm{SE})^{\mathrm{a}}\end{array}$} & \multirow{2}{*}{$\begin{array}{l}\text { Leaf width } \\
\quad(\mathbf{m m}) \\
(\text { mean } \pm \mathrm{SE})^{\mathrm{a}}\end{array}$} \\
\hline & 2,4-D & BAP & & & & & & \\
\hline- & - & 0.0 & $30 \pm 0.12^{b}$ & $1.00 \pm 0.00^{\mathrm{e}}$ & $15.00 \pm 0.00^{\mathrm{i}}$ & $15.00 \pm 0.00^{\mathrm{b}}$ & $13.57 \pm 0.27^{\mathrm{k}}$ & $10.30 \pm 0.23^{\mathrm{k}}$ \\
\hline- & - & 1.0 & $100 \pm 0.00^{\mathrm{a}}$ & $2.00 \pm 0.00^{\mathrm{c}}$ & & & & \\
\hline- & - & 3.0 & $100 \pm 0.00^{\mathrm{a}}$ & $2.40 \pm 0.24^{\mathrm{b}}$ & $72.40 \pm 0.24^{\mathrm{a}}$ & $10.80 \pm 0.73^{\mathrm{efgh}}$ & $39.35 \pm 0.12^{\mathrm{b}}$ & $25.44 \pm 0.82^{\mathrm{a}}$ \\
\hline- & - & 5.0 & $100 \pm 0.00^{\mathrm{a}}$ & $2.00 \pm 0.00^{\mathrm{c}}$ & $27.00 \pm 0.12^{\text {fghi }}$ & $12.20 \pm 0.48^{\mathrm{cde}}$ & $20.45 \pm 0.47^{\mathrm{j}}$ & $12.31 \pm 0.36^{\mathrm{j}}$ \\
\hline 0.5 & - & 0.0 & $100 \pm 0.00^{\mathrm{a}}$ & $2.00 \pm 0.00^{\mathrm{c}}$ & $49.60 \pm 0.97^{\mathrm{bcd}}$ & $12.60 \pm 0.24^{\text {cde }}$ & $31.88 \pm 0.45^{\mathrm{de}}$ & $20.65 \pm 0.55^{\mathrm{de}}$ \\
\hline 0.5 & - & 1.0 & $100 \pm 0.00^{\mathrm{a}}$ & $2.00 \pm 0.00^{\mathrm{c}}$ & $48.40 \pm 0.50^{\mathrm{bcd}}$ & $12.00 \pm 0.00^{\mathrm{cdef}}$ & $32.80 \pm 0.81^{\mathrm{d}}$ & $21.86 \pm 0.62^{\text {cde }}$ \\
\hline 0.5 & - & 3.0 & $100 \pm 0.00^{\mathrm{a}}$ & $2.00 \pm 0.00^{\mathrm{c}}$ & & & & \\
\hline 0.5 & - & 5.0 & $100 \pm 0.00^{\mathrm{a}}$ & $2.00 \pm 0.00^{\mathrm{c}}$ & $43.60 \pm 0.39^{\mathrm{cd}}$ & $10.60 \pm 0.24^{\mathrm{efgh}}$ & $27.62 \pm 0.42^{\mathrm{fg}}$ & $17.62 \pm 0.22^{\mathrm{fg}}$ \\
\hline 1.0 & - & 0.0 & $100 \pm 0.00^{\mathrm{a}}$ & $2.00 \pm 0.00^{\mathrm{c}}$ & $72.40 \pm 0.97^{\mathrm{a}}$ & $11.20 \pm 0.73^{\mathrm{defg}}$ & $34.64 \pm 0.83^{\mathrm{cd}}$ & $24.50 \pm 0.60^{\mathrm{ab}}$ \\
\hline 1.0 & - & 1.0 & $100 \pm 0.00^{\mathrm{a}}$ & $3.60 \pm 0.24^{\mathrm{a}}$ & $76.40 \pm 0.97^{\mathrm{a}}$ & $18.20 \pm 0.73^{\mathrm{a}}$ & $42.44 \pm 0.81^{\mathrm{a}}$ & $26.20 \pm 0.90^{\mathrm{a}}$ \\
\hline 1.0 & - & 3.0 & $100 \pm 0.00^{\mathrm{a}}$ & $2.00 \pm 0.00^{\mathrm{c}}$ & $38.40 \pm 0.97^{\mathrm{def}}$ & $13.00 \pm 0.00^{\mathrm{cd}}$ & $27.00 \pm 0.54^{\mathrm{fgh}}$ & $17.26 \pm 0.35^{\mathrm{fg}}$ \\
\hline 1.0 & - & 5.0 & $100 \pm 0.00^{\mathrm{a}}$ & $2.00 \pm 0.00^{\mathrm{c}}$ & $55.60 \pm 0.34^{\mathrm{bc}}$ & $10.60 \pm 0.24^{\mathrm{efgh}}$ & $37.39 \pm 0.14^{\mathrm{bc}}$ & $22.60 \pm 0.61^{\mathrm{cd}}$ \\
\hline- & 0.5 & 0.0 & $100 \pm 0.00^{\mathrm{a}}$ & $1.20 \pm 0.20^{\mathrm{de}}$ & & & & $23.36 \pm 0.91^{b c}$ \\
\hline- & 0.5 & 1.0 & $100 \pm 0.00^{\mathrm{a}}$ & $1.00 \pm 0.00^{\mathrm{e}}$ & $41.80 \pm 0.38^{\mathrm{de}}$ & $9.60 \pm 0.10^{\mathrm{gh}}$ & $29.37 \pm 0.17^{\mathrm{ef}}$ & $20.22 \pm 0.11^{\mathrm{e}}$ \\
\hline- & 0.5 & 3.0 & $100 \pm 0.00^{\mathrm{a}}$ & $1.00 \pm 0.00^{\mathrm{e}}$ & $30.80 \pm 0.11^{\text {efghi }}$ & $10.20 \pm 0.37^{\mathrm{fgh}}$ & $26.49 \pm 0.11^{\mathrm{gh}}$ & $18.15 \pm 0.83^{f}$ \\
\hline- & 0.5 & 5.0 & $100 \pm 0.00^{\mathrm{a}}$ & $1.00 \pm 0.00^{\mathrm{e}}$ & $18.60 \pm 0.81^{\mathrm{hi}}$ & $13.60 \pm 0.14^{\mathrm{bc}}$ & $20.52 \pm 0.55^{j}$ & $13.60 \pm 0.36^{\mathrm{ij}}$ \\
\hline- & 1.0 & 0.0 & $100 \pm 0.00^{\mathrm{a}}$ & $1.00 \pm 0.00^{\mathrm{e}}$ & $40.40 \pm 0.74^{\mathrm{de}}$ & $9.20 \pm 0.91^{\mathrm{hi}}$ & $24.26 \pm 0.70^{\mathrm{hi}}$ & $12.10 \pm 0.48^{\mathrm{j}}$ \\
\hline- & 1.0 & 1.0 & $100 \pm 0.00^{\mathrm{a}}$ & $1.00 \pm 0.00^{\mathrm{e}}$ & $54.60 \pm 0.52^{\mathrm{bc}}$ & $6.20 \pm 0.48^{\mathrm{j}}$ & $36.45 \pm 0.82^{\mathrm{bc}}$ & $22.38 \pm 0.86^{\mathrm{cd}}$ \\
\hline- & 1.0 & 3.0 & $100 \pm 0.00^{\mathrm{a}}$ & $1.40 \pm 0.24^{\mathrm{d}}$ & $31.14 \pm 0.82^{\mathrm{efg}}$ & $12.60 \pm 0.40^{\text {cde }}$ & $26.31 \pm 0.12^{\mathrm{ghi}}$ & $14.92 \pm 0.54^{\mathrm{hi}}$ \\
\hline- & 1.0 & 5.0 & $100 \pm 0.00^{\mathrm{a}}$ & $1.00 \pm 0.00^{\mathrm{e}}$ & $23.40 \pm 0.27^{\mathrm{ghi}}$ & $7.60 \pm 0.60^{\mathrm{ij}}$ & $23.47 \pm 0.10^{\mathrm{i}}$ & $16.05 \pm 0.56^{\mathrm{gh}}$ \\
\hline
\end{tabular}

Similar letters within the same columns mean no significant difference at $p \leq 0.05$ by DMRT.

${ }^{\mathrm{a}}$ Values represent means \pm standard error.

In the present study, it was found that the development of root formation was significantly promoted by MS medium contained $0.1 \%(\mathrm{w} / \mathrm{v}) \mathrm{AC}$ and supplemented with BAP at different concentrations $(0$, 1.0, 3.0 and $5.0 \mathrm{mg} / \mathrm{L})$ either singly or in combination with NAA and 2,4-D (0.5 and $1.0 \mathrm{mg} / \mathrm{L})$ (Figure 2). The presences of both NAA and BAP on the medium significantly promote root development. The addition of auxin, NAA or 2,4-D led to an increase in the number of roots. The higher number of roots per explant was produced on a culture medium supplemented with both $1.0 \mathrm{mg} / \mathrm{L}$ NAA and BAP (Table 2 and Figure 2C). Minimum root number (9.80 \pm 0.20 roots) was obtained in the control medium (Table 2 and Figure 2A). However, the length of roots was inversely proportional to the $1.0 \mathrm{mg} / \mathrm{L}$ NAA in combination with BAP concentration. The roots arising from the basal end of shoots were large and vigorous. The medium containing $3.0 \mathrm{mg} / \mathrm{L}$ BAP resulted in the maximum root length $(62.40 \pm 0.28$ roots) (Table 2 and Figure 2B). 
Table 2 Effects of auxins with BAP on root development of Anubias heterophylla after 60 days of culture. All culture mediums were added with $0.1 \%(\mathrm{w} / \mathrm{v}) \mathrm{AC}$.

\begin{tabular}{|c|c|c|c|c|c|}
\hline \multicolumn{3}{|c|}{$\begin{array}{c}\text { Growth regulators } \\
(\mathrm{mg} / \mathrm{L})\end{array}$} & \multirow{2}{*}{$\begin{array}{c}\text { Root } \\
\text { Formation }(\%) \\
(\text { mean } \pm \mathrm{SE})^{\mathrm{a}} \\
\end{array}$} & \multirow{2}{*}{$\begin{array}{c}\text { Number of roots per } \\
\text { explant } \\
(\text { mean } \pm \mathrm{SE})^{\mathrm{a}}\end{array}$} & \multirow{2}{*}{$\begin{array}{c}\text { Root length } \\
(\mathrm{mm}) \\
(\mathrm{mean} \pm \mathrm{SE})^{\mathrm{a}} \\
\end{array}$} \\
\hline NAA & 2,4-D & BAP & & & \\
\hline- & - & 0.0 & $100 \pm 0.00^{\mathrm{a}}$ & $9.80 \pm 0.20^{\mathrm{ef}}$ & $31.64 \pm 0.24^{\mathrm{h}}$ \\
\hline- & - & 1.0 & $100 \pm 0.00^{\mathrm{a}}$ & $18.60 \pm 0.46^{\mathrm{ab}}$ & $39.52 \pm 0.10^{\mathrm{efg}}$ \\
\hline- & - & 3.0 & $100 \pm 0.00^{\mathrm{a}}$ & $12.20 \pm 0.20^{\text {cdef }}$ & $62.40 \pm 0.28^{\mathrm{a}}$ \\
\hline- & - & 5.0 & $100 \pm 0.00^{\mathrm{a}}$ & $16.00 \pm 0.24^{\mathrm{abcd}}$ & $50.25 \pm 0.21^{\mathrm{b}}$ \\
\hline 0.5 & - & 0.0 & $100 \pm 0.00^{\mathrm{a}}$ & $16.40 \pm 0.97^{\mathrm{abcd}}$ & $33.75 \pm 0.71^{\mathrm{gh}}$ \\
\hline 0.5 & - & 1.0 & $100 \pm 0.00^{\mathrm{a}}$ & $10.80 \pm 0.48^{\mathrm{def}}$ & $46.85 \pm 0.25^{\mathrm{bcd}}$ \\
\hline 0.5 & - & 3.0 & $100 \pm 0.00^{\mathrm{a}}$ & $13.20 \pm 0.48^{\text {bcdef }}$ & $50.90 \pm 0.26^{\mathrm{b}}$ \\
\hline 0.5 & - & 5.0 & $100 \pm 0.00^{\mathrm{a}}$ & $10.00 \pm 0.00^{\mathrm{ef}}$ & $35.90 \pm 0.26^{\mathrm{fgh}}$ \\
\hline 1.0 & - & 0.0 & $100 \pm 0.00^{\mathrm{a}}$ & $13.20 \pm 0.73^{\text {bcdef }}$ & $46.84 \pm 0.22^{\mathrm{bcd}}$ \\
\hline 1.0 & - & 1.0 & $100 \pm 0.00^{\mathrm{a}}$ & $19.80 \pm 0.20^{\mathrm{a}}$ & $50.17 \pm 0.16^{\mathrm{b}}$ \\
\hline 1.0 & - & 3.0 & $100 \pm 0.00^{\mathrm{a}}$ & $13.60 \pm 0.14^{\text {bcdef }}$ & $48.23 \pm 0.16^{\mathrm{bc}}$ \\
\hline 1.0 & - & 5.0 & $100 \pm 0.00^{\mathrm{a}}$ & $8.80 \pm 0.48^{\mathrm{f}}$ & $44.59 \pm 0.27^{\text {bcde }}$ \\
\hline- & 0.5 & 0.0 & $100 \pm 0.00^{\mathrm{a}}$ & $18.40 \pm 0.11^{\mathrm{ab}}$ & $22.90 \pm 0.10^{\mathrm{i}}$ \\
\hline- & 0.5 & 1.0 & $100 \pm 0.00^{\mathrm{a}}$ & $17.20 \pm 0.91^{\mathrm{abc}}$ & $30.43 \pm 0.11^{\mathrm{h}}$ \\
\hline- & 0.5 & 3.0 & $100 \pm 0.00^{\mathrm{a}}$ & $15.20 \pm 0.23^{\mathrm{abcde}}$ & $43.15 \pm 0.18^{\text {cde }}$ \\
\hline- & 0.5 & 5.0 & $100 \pm 0.00^{\mathrm{a}}$ & $16.00 \pm 0.16^{\mathrm{abcd}}$ & $40.33 \pm 0.21^{\mathrm{def}}$ \\
\hline- & 1.0 & 0.0 & $100 \pm 0.00^{\mathrm{a}}$ & $13.60 \pm 0.12^{\text {bcdef }}$ & $39.52 \pm 0.16^{\mathrm{efg}}$ \\
\hline- & 1.0 & 1.0 & $100 \pm 0.00^{\mathrm{a}}$ & $18.40 \pm 0.97^{\mathrm{ab}}$ & $41.87 \pm 0.23^{\text {cdef }}$ \\
\hline- & 1.0 & 3.0 & $100 \pm 0.00^{\mathrm{a}}$ & $16.00 \pm 0.54^{\mathrm{abcd}}$ & $39.21 \pm 0.25^{\mathrm{efg}}$ \\
\hline- & 1.0 & 5.0 & $100 \pm 0.00^{\mathrm{a}}$ & $15.20 \pm 0.33^{\mathrm{abcde}}$ & $42.63 \pm 0.21^{\mathrm{cde}}$ \\
\hline
\end{tabular}

Similar letters within the same columns mean no significant difference at $p \leq 0.05$ by DMRT.

${ }^{\mathrm{a}}$ Values represent means \pm standard error. 

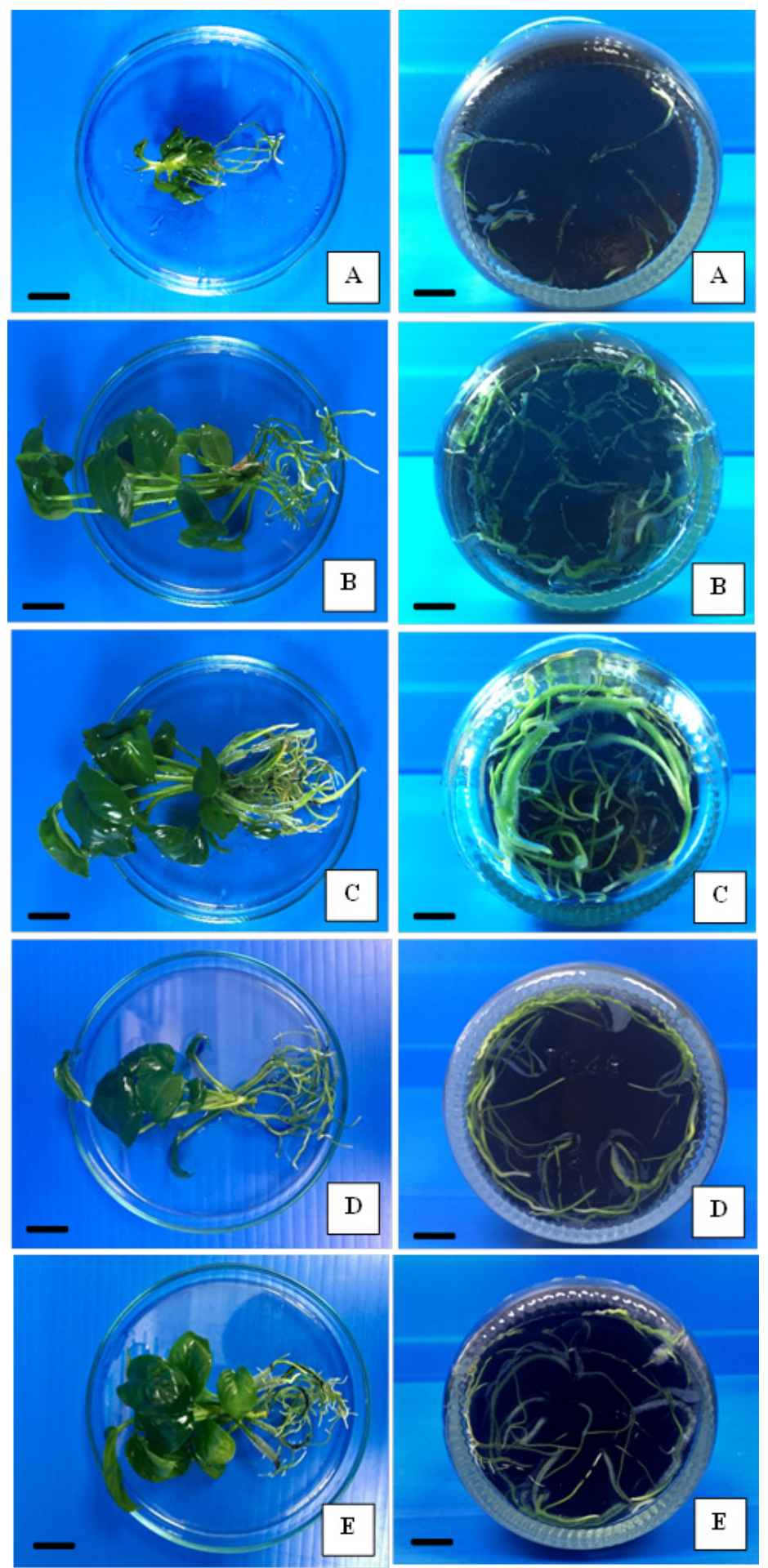

Figure 2 Effects of auxins with BAP on root development of Anubias heterophylla after 60 days of culture. (A; right-left) Control, (B; right-left) $3.0 \mathrm{mg} / \mathrm{L}$ BAP, (C; right-left) $1.0 \mathrm{mg} / \mathrm{L} \mathrm{NAA}+1.0 \mathrm{mg} / \mathrm{L}$ $\mathrm{BAP}$, (D; right-left) $0.5 \mathrm{mg} / \mathrm{L}$ 2,4-D and (E; right-left) $1.0 \mathrm{mg} / \mathrm{L}$ 2,4-D+3.0 mg/L BAP (Scale bar $=1 \mathrm{~cm}$ ).

\section{Hardening and establishment of tissue culture plantlets}

Root formation and shoot elongation of A. heterophylla occurred at 60 days of culture. When the complete plantlets reach a length of $5-7 \mathrm{~cm}$, agar was carefully washed from these plantlets. They were transferred to small clay pots containing tap water under greenhouse conditions. The percentage of 
survival plantlets was $100 \%$ under greenhouse conditions (Figures 3A - 3F). During the transferring process, the regenerated $A$. heteropylla plantlets showed normal phenotypic characteristics similar with their donor plant.
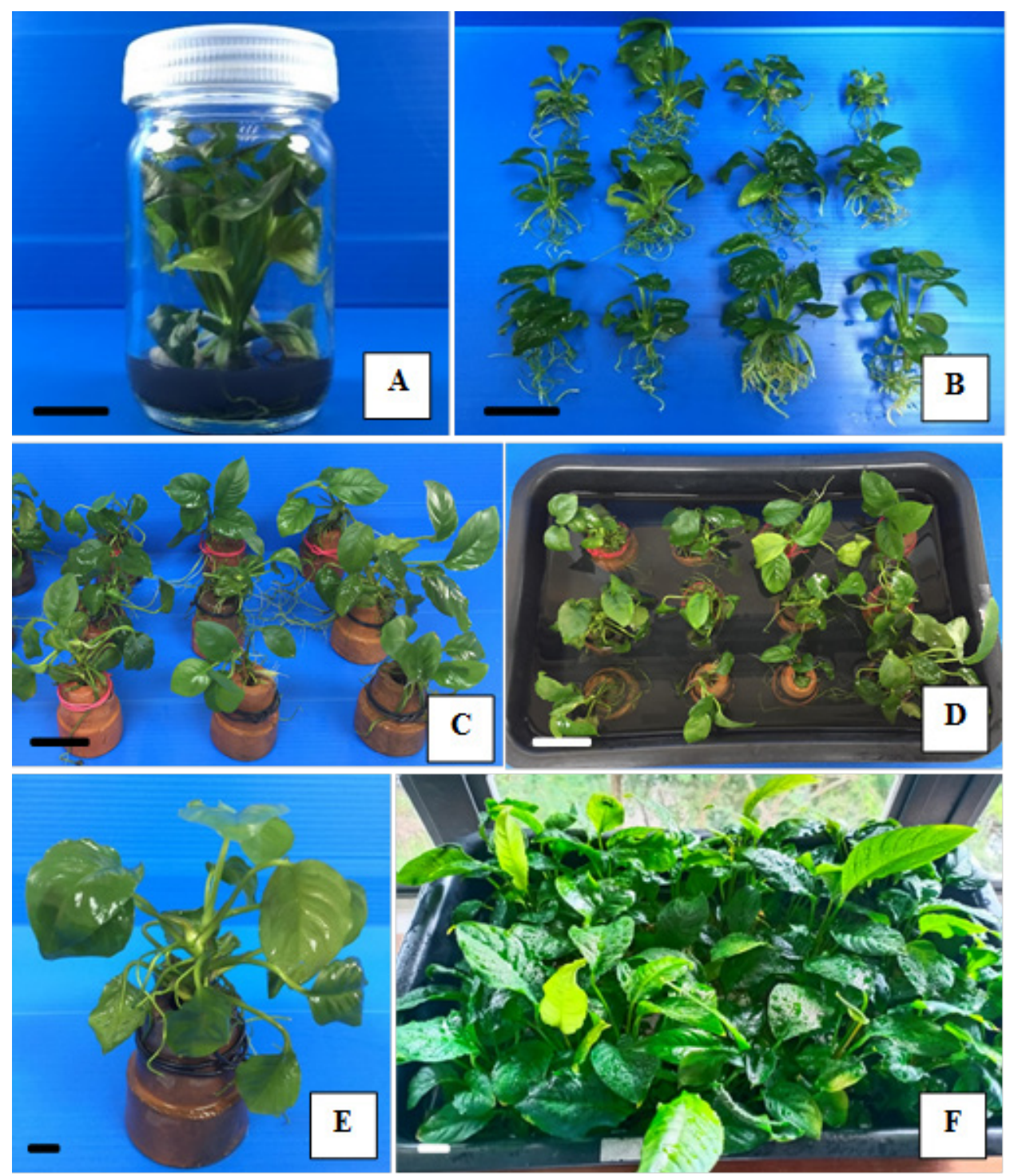

Figure 3 Acclimatization of Anubias heterophylla through shoot tip explants: (A - B) 60-day-old regenerated shoots on MS medium supplemented with plant growth regulators, $(\mathrm{C}-\mathrm{D})$ hardened plantlet of Anubias heterophylla into small clay pots containing with tap water under greenhouse conditions after 30 days and $(\mathrm{E}-\mathrm{F})$ the regenerated plantlets were successfully acclimatized in the greenhouse after 60 days (Scale bar $=1 \mathrm{~cm})$.

Micropropagation offers a viable alternative for conventional methods because it can also be used as a complementary strategy for the conservation and utilization of genetic resources. Further, in vitro plant regeneration is an easy and economical way for obtaining a large number of consistently uniform and true to type plants within a short period of time [12]. The present study focuses on the development of a micropropagation protocol for true to type plants of $A$. heterophylla, a valuable ornamental aquatic plant. In the present study, the highest number of shoots per explants $(3.60 \pm 0.24)$ was formed in the culture medium containing $1.0 \mathrm{mg} / \mathrm{L}$ NAA in combination with $1.0 \mathrm{mg} / \mathrm{L} \mathrm{BAP}$, followed by in the culture medium with $3.0 \mathrm{mg} / \mathrm{L}$ BAP $(2.40 \pm 0.24)$. In the culture medium with $1.0 \mathrm{mg} / \mathrm{L}$ NAA and $1.0 \mathrm{mg} / \mathrm{L}$ BAP, $100 \%$ of the cultured explants regenerated new shoots within 60 days. 
Kanchanapoom et al. [4] has reported culture initiation and shoot multiplication from the lateral shoot tip explants of $A$. barteri var. Nana on MS medium containing $3.0 \mathrm{mg} / \mathrm{L} \mathrm{BAP}$. But in the present study, in A. heterophylla, a combination of NAA and BAP was found to be suitable for plant regeneration. The beneficial effect of BAP on shoot regeneration and proliferation and induction of multiple shoots was reported in other species [5,13-15]. Some species may require a low concentration of auxins in combination with high levels of cytokinins to increase shoot proliferation [16]. A study by Abadi and Kaviani [17] on micropropagation of Aloe vera L. using BA, NAA and IBA showed that the best proliferation of shoot per explants was shown on medium supplemented with $0.5 \mathrm{mg} / \mathrm{L}$ NAA containing $0.5 \mathrm{mg} / \mathrm{L} \mathrm{BA}$. In our work, the combination of NAA and BAP, both at $1.00 \mathrm{mg} / \mathrm{L}$ promoted shoot proliferation.

The presence of auxin (NAA or 2,4-D) along with BAP increased the shoot proliferation of organogenesis. The frequency and response of in vitro shoot regeneration are affected by the type of explants and the concentration of PGRs [18-20]. The promoting effect of auxin and cytokinin combinations on organogenic has been well documented [21,22]. In vitro shoot multiplication relies largely on medium formulations containing BAP as the major PGRs in combination with a low concentration of NAA [23]. Kim et al. [24] indicated that in vitro shoot proliferation and multiplication are largely based on media formulations containing cytokinins as major plant growth regulators, although low concentrations of auxins or $\mathrm{GA}_{3}$ are also essential. The results of the present study demonstrated that the inclusion of $1.0 \mathrm{mg} / \mathrm{L}$ NAA and $1.0 \mathrm{mg} / \mathrm{L}$ BAP to the culture media increased the shoot multiplication and root formation. This result is similar to the findings on optimal NAA and BAP concentration [25]. This observation agreed with the earlier reports of Ahmad and Anis [26]. They suggested that the cytokinin: Auxin ratio is an important factor for the differentiation of adventitious shoots as elucidated by Skoog and Miller [27].

The effect of auxins on plant development has led many researchers to characterize this hormone as a plant morphogen [28-32]. Polar auxin transport via PIN proteins directs auxin to a specific location in the plant body during development and plays a central role in tropic growth, apical dominance, lateral root initiation, vascular development, and embryo patterning [28]. PGRs are the initial factors inducing morphogenic responses in plants in vitro [33]. Evidence from previous reports indicates that combinations of auxin and cytokinin are more effective for shoot organogenesis at equal ratios (1:1) or even lower [3436]. Therefore, 2 combinations of PGRs at equal ratios (1 NAA:1 BAP and 1 2,4-D:1 BAP) were tested in this study at 2 different absolute concentrations; the medium concentration $(1.0 \mathrm{mg} / \mathrm{L} \mathrm{NAA}+1.0 \mathrm{mg} / \mathrm{L}$ BAP) stimulated shoot formation at a significantly faster and more efficient rate than did the other one concentration (Table 1). A reduced response was observed when the media were supplemented with a 2,4-D absolute concentration (Table 1), which may be mainly caused by auxins. As auxins are responsible for apical dominance [37], inhibiting effects on shoot organogenesis have also been reported in vitro [34]. Sensitivity to changes in hormone concentration (both endogenous and exogenous) is a key requirement for somatic cells to reach "embryogenic status". SE induction is favored by auxins [38], mostly 2,4-D [39, 40], with or without a low level of cytokinin [41]. In this study, a mixture of NAA and BAP in the media successfully induced shoots (Table 1). Auxin signaling affects somatic embryogenesis by altering the expression patterns of genes involved in auxin-induced growth and development [42]. Auxin signals can induce the synthesis of embryonic proteins during somatic embryogenesis but can act as negative factors by inhibiting the synthesis of protein needed for SE development [43].

In the present study, MS medium had a significantly high $(p \leq 0.05)$ effect on both shoot multiplication and root formation. MS medium containing $0.1 \%(\mathrm{w} / \mathrm{v}) \mathrm{AC}$ and supplemented with 1.0 $\mathrm{mg} / \mathrm{L} \mathrm{NAA}$ and $1.0 \mathrm{mg} / \mathrm{L} \mathrm{BAP}$ was found to perform better in terms of root formation. The addition of auxin, $\alpha$-Naphthalene acetic acid (NAA) or 2,4-Dichlorophenoxy acetic acid (2,4-D) led to an increase in the number of roots. The maximum number of roots $(19.80 \pm 0.20$ roots $)$ per explant was observed after 60 days of culture on MS medium containing $0.1 \%(\mathrm{w} / \mathrm{v}) \mathrm{AC}$ and supplemented with $1.0 \mathrm{mg} / \mathrm{L} \mathrm{NAA}$ and $1.0 \mathrm{mg} / \mathrm{L}$ BAP. Irrespective of the auxins used, it showed $100 \%$ rooting. Our findings demonstrated that the addition of BAP and NAA in culture media was effective for increasing the number of root and root lengths. The current study showed the positive effect of NAA on root induction and root length. Some studies showed the positive effect of cytokinins on rooting [44]. Auxins are routinely used for induction of rooting for in vitro shoots [45-48]. The application of auxins promotes the enzyme activities that regulate various pathways of protein, carbohydrates, nitrogen, and polyphenolic metabolism which could influence root formation [46]. In the present experiment, the maximum number of roots $(19.80 \pm 0.20$ roots) per explant was observed after 60 days of culture on MS medium containing $0.1 \%(\mathrm{w} / \mathrm{v}) \mathrm{AC}$ and supplemented with $1.0 \mathrm{mg} / \mathrm{L}$ NAA and $1.0 \mathrm{mg} / \mathrm{L}$ BAP. Previous studies have shown that in herbaceous 
plant a very low concentration of strong auxins is effective in induction of rooting [49-51]. Apart from root number, their length is also critical in the survival of plants during hardening [52].

Regarding the in vitro acclimatization of $A$. heterophylla plantlets, our findings are consistent with the $100 \%$ survival rate reported for this genus by several authors [4,53]. These results contrasted with those observed for some plant species; where a high mortality has occurred during the acclimatization process due to stomatal dysfunction, weak root systems, and/or poor cuticle development [54]. Therefore, the protocol established in this study also ensures rapid and inexpensive rooting, as well as an adequate survival rate of this commercially important species.

\section{Conclusions}

We have demonstrated the establishment of a rapid in vitro propagation of $A$. heterophylla through shoot tip culture. MS medium containing $0.1 \%(\mathrm{w} / \mathrm{v}) \mathrm{AC}$ in combination with $1.0 \mathrm{mg} / \mathrm{L}$ of both NAA and BAP was found to be the better medium for the regeneration of $A$. heterophylla. The plantlets formed from the study were well developed with healthy root and shoot before transferring into a nursery. All new progenies found survive following the transfer.

\section{Acknowledgements}

This research was financially supported by Prince of Songkla University, Pattani campus, Pattani, Thailand. The authors would like to thank Department of Technology and Industries, Faculty of Science and Technology, Prince of Songkla University, Pattani campus, for providing laboratory facilities for this investigation.

\section{References}

[1] Anubias Heterophylla Aquatic Plants, Available at: https:/shop.glassaqua.com/products/ anubias-heterophylla, accessed April 2020.

[2] J Carter and AHLAN Gunawardena. Regeneration of the aquatic monocot Aponogeton madagascariensis (lace plant) through callus induction. Aquat. Bot. 2011; 94, 143-9.

[3] JO Myung, RN Hye, C Hong-Keun, RL Jang and WK Suk. High frequency plant regeneration system for Nymphoides coreana via somatic embryogenesis from zygotic embryo-derived embryogenic cell suspension cultures. Plant Biotechnol. Rep. 2010; 4, 125-8.

[4] K Kanchanapoom, P Chunui and K Kanchanapoom. Micropropagation of Anubias barteri var. Nana from shoot tip culture and the analysis of ploidy stability. Not. Bot. Horti. Agrobo. ClujNapoca 2012; 40, 148-51.

[5] S Klaocheed, W Jehsu, W Choojun, K Thammasiri, S Prasertsongskun and S Rittirat. Induction of direct shoot organogenesis from shoot tip explants of an ornamental aquatic plant, Cryptocoryne wendtii. Walailak J. Sci. Tech. 2020; 17, 293-302.

[6] CZ Liu, SJ Murch, JC Jain and PK Saxena. Goldenseal (Hydrastis canadensis L.): In vitro regeneration for germplasm conservation and elimination of heavy metal contamination. In Vitro Cell. Dev. Biol. Plant 2004; 40, 75-9.

[7] T İzgü, B Sevindik, P Çürük, Ö Şimşek, YA Kaçar, JATD Silva and YY Mendi. Development of an efficient regeneration protocol for four Cyclamen species endemic to Turkey. Plant Cell Tissue Organ Cult. 2016; 127, 95-113.

[8] B Khilwani, A Kaur, R Ranjan and A Kumar. Direct somatic embryogenesis and encapsulation of somatic embryos for in vitro conservation of Bacopa monnieri (L.) Wettst. Plant Cell Tissue Organ Cult. 2016; 127, 433-42.

[9] V Patial, M Sharma and A Bhattacharya. Potential of thidiazuron in improved micropropagation of Picrorhiza kurroa - an endangered medicinal herb of alpine Himalaya. Plant Biosyst. 2015; 151, 729-36.

[10] ZM Ren, YP Xia, D Zhang, Y Li and Y Wu. Cytological analysis of the bulblet initiation and development in Lycoris species. Scientia Horticulturae 2017; 218, 72-9.

[11] T Murashige and F Skoog. A revised medium for rapid growth and bioassays with tobacco tissue cultures. Physiol. Plant. 1962; 15, 473-97.

[12] K Yadav, A Aggarwal and N Singh. Evaluation of genetic fidelity among micropropagated plants of Gloriosa superba L. using DNA-based markers - a potential medicinal plant. Fitoterapia 2013; 89, 265-70. 
[13] DT Nhut. The control of In vitro direct main stem formation of Lilium longiflorum derived from receptacle culture and rapid propagation by using In vitro stem nodes. Plant Growth Regul. 2003; 40, 179-84.

[14] CB Fráguas, M Pasqual, LF Dutra and O Cazzeta. Micropropagation of fig (Ficus carica L.) 'Roxo de Valinhos' plants. In Vitro Cell Dev. Biol. Plant. 2004; 40, 471-4.

[15] PR Poudel, I Kataoka and R Mochioka. Effect of plant growth regulators on in vitro propagation of Vitis ficifolia var. ganeba and its interspecific hybrid grape. Asian J. Plant Sci. 2005; 4, 466-71.

[16] D Van Staden. Plant growth regulators, II: cytokinins, their analogues and inhibitors. In: EF George, MA Hall and GJD Klerk (Eds.). Plant propagation by tissue culture. $3^{\text {rd }}$ ed. Springer, Netherlands, 2008, p. 205-26.

[17] DH Abadi and BK Livani. In vitro proliferation of an important medicinal plant Aloe - a method for rapid production. Aust. J. Crop Sci. 2010; 4, 216-22.

[18] J Gubis, Z Lajchova and J Farago. Effect of genotype and explants type on shoot regeneration in tomato (Lycopersicon esculentum Mill.). Czech J. Genet. Plant Breed. 2003; 39, 9-14.

[19] S Ishag, MG Osman and MM Khalafalla. Effects of growth regulators, explants and genotype on shoot regeneration in tomato (Lycopersicon esculentum cv Omdurman). Int. J. Sustain. Crop Prod. 2009; 4, 7-13.

[20] S Mukhtar, N Ahmad, MI Khan, M Anis and IM Aref. Influencing micropropagation in Clitoria ternatea L. through the manipulation of TDZ levels and use of different explants types. Physiol. Mol. Biol. Plants 2012; 18, 381-6.

[21] SD Yancheva, S Golubowicz, E Fisher, MA Lev-Yadum and MA Flaishman. Auxin type and timing of application determine the activation of the developmental program during in vitro organogenesis in apple. Plant Sci. 2003; 165, 299-309.

[22] S Ignacimuthu, S Arockiasamy, M Antonysamy and P Ravichandran. Plant regeneration through somatic embryogenesis from mature leaf explants of Eryngium foetidum, a condiment. Plant Cell Tissue Organ Cult. 1999; 56, 131-7.

[23] W Xing, M Boa, H Qin and G Ning. Micropropagation of Rosa rugose through axillary shoot proliferation. Acta Biol. Cracov. Bot. 2010; 52, 69-75.

[24] CJU Kim, SO Jee and JD Chung. In vitro micropropagation of Rosa hybrid L. J. Plant Biotechnol. $2003 ; 5,115-9$.

[25] CL Kuo, DC Agrawal, HC Chang, YT Chiu, CP Huang, YL Chen, SH Huang and HS Tsay. In vitro culture and production of syringing and rutin in Saussurea involucrata (Kar. Et Kir.) - an endangered medicinal plant. Bot. Stud. 2015; 56, 12.

[26] N Ahmad and M Anis. Rapid plant regeneration protocol for cluster bean (Cyamopsis tetragonoloba L. Taub.). J. Hortic. Sci. Biotechnol. 2007; 82, 585-9.

[27] F Skoog and CO Miller. Chemical regulation of growth and organ function in plant tissues cultured in vitro. Symp. Soc. Exp. Biol. 1957; 11, 118-30.

[28] S Vanneste and J Friml. Auxin: A trigger for change in plant development. Cell 2009; 136, $1005-$ 16.

[29] I Blilou, J Xu, M Wildwater, V Willemsen, I Paponov, J Friml, R Heidstra, M Aida, K Palme and B Scheres. The PIN auxin efflux facilitator network controls growth and patterning in Arabidopsis roots. Nature 2005; 433, 39-44.

[30] N Braun, J Wyrzykowska, P Muller, K David, D Couch, C Perrot-Reichenmann and AJ Fleming. Conditional repression of AUXIN BINDING PROTEIN1 reveals that it coordinates cell division and cell expansion during postembryonic shoot development in Arabidopsis and tobacco. Plant Cell 2008; 20, 2746-62.

[31] Y Cheng, X Dai and Y Zhao. Auxin biosynthesis by the YUCCA flavin monooxygenases controls the formation of floral organs and vascular tissues in Arabidopsis. Genes Dev. 2006; 20, 1790-9.

[32] Y Cheng, X Dai and Y Zhao. Auxin synthesized by the YUCCA flavin monooxygenases is essential for embryogenesis and leaf formation in Arabidopsis. Plant Cell 2007; 19, 2430-9.

[33] D Miroshnichenko, I Chaban, M Chernobrovkina and S Dolgov. Protocol for efficient regulation of in vitro morphogenesis in einkorn (Triticum monococcum L.), a recalcitrant diploid wheat species. PLoS One 2017; 12, e0173533.

[34] AM Dimech, R Cross, R Ford and PWJ Taylor. Micropropagation of Gymea lily (Doryanthes excelsa Corrêa) from New South Wales, Australia. Plant Cell Tissue Organ Cult. 2007; 88, $157-$ 65.

[35] EV Boltenkov, VG Rybin and EV Zarembo. Specific features of cultivation of Iris ensata Thunb. callus tissue. Appl. Biochem. Microbiol. 2004; 40, 206-12. 
[36] JL Ramsay, DS Galitz and CW Lee. Basal medium and sucrose concentration influence regeneration of Easter lily in ovary culture. HortScience 2003; 38, 404-6.

[37] IA Tamas. Hormonal regulation of apical dominance. Springer, Amsterdam, 1995.

[38] NS Rangaswamy. Somatic embryogenesis in angiosperm cell tissue and organ cultures. Proc. Plant Sci. 1986; 96, 247-71.

[39] A Ji, X Geng, Y Zhang and G Wu. Advances in somatic embryogenesis research of horticultural Plants. Am. J. Plant Sci. 2011; 2, 727-32.

[40] VM Jimenez. Regulation of in vitro somatic embryogenesis with emphasis on to the role of endogenous hormones. Rev. Bras. Fisiol. Veg. 2001; 13, 196-223.

[41] AP Sagare, YL Lee, TC Lin, CC Chen and HS Tsay. Cytokinin-induced somatic embryogenesis and plant regeneration in Corydalis yanhusuo (Fumariaceae) - a medicinal plant. Plant Sci. 2000; 160, 139-47.

[42] WM Gray. Hormonal regulation of plant growth and development. PLoS Biol. 2004; 2 , e311.

[43] X Yang and X Zhang. Regulation of somatic embryogenesis in higher plants. Crit. Rev. Plant Sci. 2010; 29, 36-57.

[44] F Gomes, M Simões, ML Lopes and M Canhoto. Effect of plant growth regulators and genotype on the micropropagation of adult trees of Arbutus unedo L. (strawberry tree). New Biotechnol. 2010; 27, 882-92.

[45] UI Shehu, LA Sani and AB Ibrahim. Auxin induced rooting of cactus pear (Opuntia ficus-indica L. Miller) cladodes for rapid on-farm propagation. Afr. J Agr. Res. 2016; 11, 898-900.

[46] P Overvoorde, H Fukaki and T Beeckman. Auxin control of root development. Cold Spring Harb. Perspect. Biol. 2010; 2, a001537.

[47] CM Fogaca and AG Fett-Neto. Role of auxin and its modulators in the adventitious rooting of Eucalyptus species differing in recalcitrance. Plant Growth Regul. 2005; 45, 1-10.

[48] TI Pop, D Pamfil and C Bellini. Auxin control in the formation of adventitious roots. Not. Bot. Horti. Agrobo. Cluj-Napoca 2011; 39, 307-16.

[49] SP Yan, RH Yang, F Wang, LN Sun and XS Song. Effect of auxins and associated metabolic changes on cuttings of hybrid aspen. Forests 2017; 8, 117.

[50] A Aygun and H Dumanoglu. In vitro shoot proliferation and in vitro and ex vitro root formation of Pyrus elaeagrifolia Pallas. Front. Plant Sci. 2015; 6, 225.

[51] N Fatima and M Anis. Role of growth regulators on in vitro regeneration and histological analysis in Indian ginseng (Withania somnifera L.) Dunal. Physiol. Mol. Biol. Plants 2012; 18, 59-67.

[52] A Pierret, CJ Christopher and MC Doussan. Conventional detection methodology is limiting our ability to understand the roles and functions of fine roots. New Phytol. 2005; 166, 967-80.

[53] GE Sheeja, A Joseph and A Korath. In vitro propagation of an ornamental aquatic plant, Anubias barterii Var. Nana petite. Int. J. Curr. Sci. 2015; 18, 1-12.

[54] A Mathur, AK Mathur, P Verma, S Yadav, ML Gupta and MP Darokar. Biological hardening and genetic fidelity testing of micro-cloned progeny of Chlorophytum borivilianum. Afr. J. Biotechnol. 2008; 7, 1046-53. 